\title{
Article \\ Construct and Priority Ranking of Factors Affecting Crowdfunding for Green Products
}

\author{
Xiu-Yue Zhang ${ }^{1}$, Jui-Che Tu ${ }^{2, *}$, Shurui Gu ${ }^{3,4, *}$, Tzu-Hsuan $\mathrm{Lu}^{2}$ and Minzhe $\mathrm{Yi}^{5}$ \\ 1 School of Art and Design, Zhejiang Sci-Tech University, Hangzhou 310018, China; zhangxiuyue@zstu.edu.cn \\ 2 Graduate School of Design, National Yunlin University of Science and Technology, Yunlin 64002, Taiwan; \\ lutzuhsuan@163.com \\ 3 Department of Business Administration, National Yunlin University of Science and Technology, \\ Yunlin 64002, Taiwan \\ 4 School of Economics, Guangzhou City University of Technology, Guangzhou 510800, China \\ 5 Institute of Zhejiang Sci-Tech University-Ouhai, Wenzhou 325000, China; minzhe@zstu.edu.cn \\ * Correspondence: tujc@yuntech.edu.tw (J.-C.T.); gusr@gcu.edu.cn (S.G.)
}

check for updates

Citation: Zhang, X.-Y.; Tu, J.-C.; Gu, S.; Lu, T.-H.; Yi, M. Construct and Priority Ranking of Factors Affecting Crowdfunding for Green Products. Processes 2022, 10, 480. https:// doi.org/10.3390/pr10030480

Academic Editors: Tsai-Chi Kuo and Yu-Chung Tsao

Received: 3 February 2022

Accepted: 25 February 2022

Published: 27 February 2022

Publisher's Note: MDPI stays neutral with regard to jurisdictional claims in published maps and institutional affiliations.

Copyright: (C) 2022 by the authors. Licensee MDPI, Basel, Switzerland. This article is an open access article distributed under the terms and conditions of the Creative Commons Attribution (CC BY) license (https:// creativecommons.org/licenses/by/ $4.0 /)$.

\begin{abstract}
This article aims to target the key factors that could positively affect crowdfunding success for green products in order to promote crowdfunding efficiency and green supply chain management. Methods: Data were collected through expert interviews and questionnaires and then processed through analytic hierarchy process (AHP) analysis. Statistical tool: This study used Expert Choice as the software for AHP analysis. Sampling: There were 20 participants ( 20 effective) in pretesting and 30 (23 effective) in formal testing. Participants were followers of green products in Taiwan. Results: (1) Twenty-four factors were abstracted to form the final construct; (2) the 24 key factors could be divided into 2 hierarchies, with 5 primary factors and 19 secondary factors; (3) among the 5 primary factors, "green diversified context" was the most influential; (4) among the 19 secondary factors, "product material is safe and non-toxic" was the most important. Conclusions: Funders would be likely to finance green products on crowdfunding platforms if these products fit the 24 key factors in orders. Implications: This research contributes to product life cycle theory and crowdfunding theory and practically improves the sustainability of green products.
\end{abstract}

Keywords: success key factor; product life cycle; public demands; sustainable crowdfunding; green supply chain management

\section{Introduction}

\subsection{Background}

Globally, the current COVID-19 pandemic is promoting a rethinking of environmental consciousness [1-3] and green consumption behavior [1,4]. Along with an increase in public awareness of health [5], environmental consciousness [6], sustainable consumption [7], and social responsibility [8], consumers tend to pay more attention to environmentally friendly green products $[9,10]$.

Compared with traditional products, green products cater more to environmental impacts $[10,11]$, consume lower energy and resources [12,13], exert fewer environmental impacts and risks [12,14], and prevent waste generation during the early product design phase [12]. These objectives align with the concept of the United Nations sustainable development goals (SDG) [15], that is, green products echo the green trend in society and conform to the needs of our time.

However, the promotion of green products potentially faces two obstacles. (1) Green products often have higher prices than general products due to their green attributes [16], which may negatively affect public purchasing willingness and further green industry development, especially in an economic slowdown due to the pandemic; (2) A corresponding 
lack of funding in the pandemic might be a barrier to developing environmentally friendly projects, particularly related to the development of new products [17].

Under these circumstances, this study examines crowdfunding for green products as an option to solve the aforementioned challenges. As a recognized method of financing ecological projects, crowdfunding has achieved a higher success rate than other ideas funded online [18]. Specifically, on the demand side, crowdfunding for green products can quickly obtain and respond to the requirements of targeted and affordable consumers, while on the supply side, crowdfunding provides access for innovative companies to obtain required capital for the production and manufacturing of new green products. Moreover, crowdfunding has been seen as an influential business model during the pandemic [19-22].

Additional questions for investigation include determining which factors are crucial for the successful crowdfunding of green products. Among these factors, which are the most influential for the sustainable development of crowdfunding? Abundant research has studied the factors contributing to crowdfunding success over the past decade, but few studies have focused on the target category of green products. Thus, little is known about the factors influencing successful crowdfunding for green products, leaving a gap in theory in the green industry on targeting key factors in crowdfunding practice for green products.

\subsection{Purpose}

Considering current business trends, industrial demand, and consumers' preferences, this study aims to investigate the sustainability of crowdfunding for green products through two clear goals:

(1) Based on the product life cycle concept, this study aims to develop a construct of key factors that could affect crowdfunding success for green products.

(2) Focusing on public demand, this work aims to clarify the priority ranking of the key factors in corresponding construct hierarchies.

\subsection{Scope}

- Type of crowdfunding: This study focuses on reward-based online crowdfunding. Specifically, in this paper, individuals financially support projects related to green products through online platforms, where backers are rewarded with tangible products rather than receiving the money back.

- Research location: This study was conducted in Taiwan, which provides a proper research context. Taiwan was once the most prosperous economic region in Asia, but its rapid industrialization generated numerous environmental problems [23], causing heated discussions of sustainable development. Regarding theory, green management [24], green products [25], green brands [26], and green design [27] were previously researched. Practically, Taiwan implemented sustainability measures, including Green Building Material Labels [28], the Taiwan Green-Mark [29], and a plastic products restriction policy [30]. Recently, crowdfunding has attracted public attention in Taiwan and generated corresponding platforms [31,32]. Therefore, the research location provided sufficient geographic and social bases for this study.

- Research perspective: This study considers two aspects when targeting key factors: product life cycle and public demand. The product life cycle is the core concept behind green products because the meaning of "green" manifests in each step of the product life cycle, including processes such as design, production, and marketing [33]. Regarding public demand, it is essential for the success of crowdfunding through online platforms, and the success largely depends on the financial support of donors. Thus, the crowdfunding process is a mirror reflecting public interest, preferences, and expectations [31,34].

- Research sample: This study obtained public feedback and expert judgment as databases. Nearly 50 participants were young people (18-39 years old) with a higher education level (college education and above), and they were followers of green prod- 
ucts. The five experts were professionals from both academia and industry who had related research or practical experience.

\subsection{Scheme}

This paper is divided into six sections. Section 1 introduces the background, purpose, and scope of the study. Section 2 reviews the theoretical literature on green product elements and crowdfunding factors, and also proposes hypotheses. Section 3 presents the research process and methods in detail. Section 4 elaborates and illustrates the results in response to the two research goals. Section 5 discusses the results theoretically and practically. Finally, Section 6 provides conclusions and offers suggestions for future research.

\section{Literature Review}

\subsection{Elements of Green Products}

As a tangible return of reward-based crowdfunding [35], the green product itself is a powerful stimulator for public choice and decisions. However, merely adopting a general word (e.g., "sustainable," "ecological") to describe a green product on crowdfunding platforms might not be persuasive to backers [17]. Considering the true meaning behind the word "green," the literature review concentrates on four key elements of green products: green product design, manufacturing, and marketing, and the green diversified context.

- Green product design: Due to the increasing awareness of sustainability, manufacturers' product-line designs are receiving greater attention [36]. Innovation and creativity are crucial for green product development [37], and green and low-carbon concepts have been highlighted in industry [38]. Additionally, the light weight of green products is a valid approach to maintaining a low-carbon footprint [39]. Green materials should follow basic principles, such as being nontoxic and harmless, as well as having low energy consumption, ease of recycling, and innovation [40]. Regarded as an effective tool, life cycle assessment is useful in the development of green product design projects [41].

- Green product manufacturing: Analyzing energy consumption is an essential task for a factory [42], and green manufacturing activities form the basis for producing green and environmentally friendly goods [43]. Quality optimization is used to improve the quality characteristics of green products, as a high-quality product means less time wasted on interruptions and restarts in the production process as well as less waste and defective products [44].

- Green product marketing: Marketing covers diversified aspects, such as public demand, branding, strategic planning, and implementation. The concern for ecoenvironment, eco-labeling, past experiences, and perceived usefulness have been identified as major influencers of green consumer behavior [45]. Product demand influences green marketing dynamics [46], and green brands impact innovation capability as well as new product success [47]. Moreover, a green marketing orientation has positive and significant effects on green consumption intentions [48].

- Green diversified context: The green context impacts each step of the product life cycle with tangible and intangible factors, such as green policy [49], green trends [50], public environmental awareness [51], green technologies [52], and green education [53].

The four key elements of green products and their value to sustainability are listed in Table 1. 
Table 1. Key elements of green products and their value to sustainability.

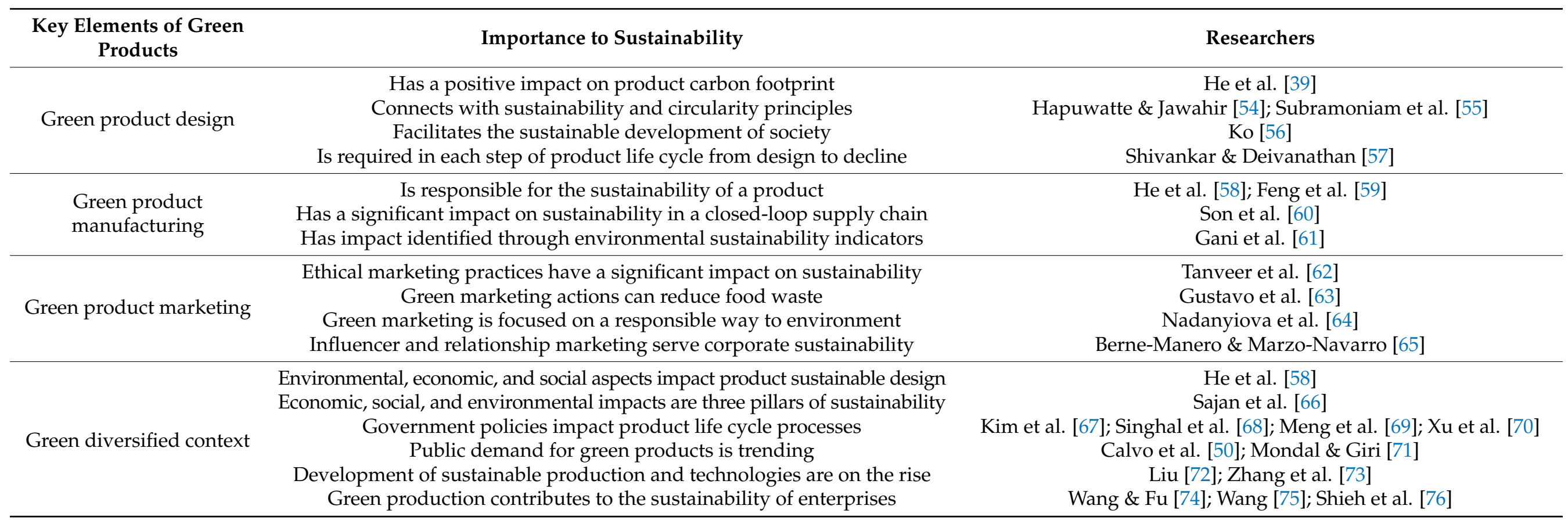




\subsection{Factors Affecting Crowdfunding Success}

Crowdfunding is a method of financing ecological projects [18], and crowdfunding platforms provide a viable alternative for financing innovative ideas [17]. Among many types of crowdfunding, reward-based crowdfunding represents the category with the highest volume of funding [77].

Factors for crowdfunding success have generated heated theoretical discussions (see Table 2). For example, Ho et al. [78] summarized three signal measures of crowdfunding from the channels of a campaign, fundraiser, and social interactions. Cosma et al. [79] concluded that the variety of partners in a platform's network influences crowdfunding success. Rossolini et al. [80] emphasized three communication strategies (message framing, green emphasis, and quantitative goals) essential for green product crowdfunding, and dos Santos Felipe et al. [81] regarded exposure times, the number of supporters, and the higher volume of rewards as three elements based on practical aspects.

Table 2. Factors affecting crowdfunding success.

\begin{tabular}{cl}
\hline Researcher & \multicolumn{1}{c}{ Factors } \\
\hline Hsieh et al. [32] & Two factors: (1) environmental elements, (2) social context \\
\hline Ho et al. [78] & $\begin{array}{l}\text { Three signal measures: (1) signals originating from the campaign (title, description, } \\
\text { spelling errors, location, and picture); (2) signals originating from the fundraiser } \\
\text { (social network, and updates); and (3) signals originating from the social } \\
\text { interaction of the fundraiser with the crowd (comments, followers, and shares) }\end{array}$ \\
\hline Cosma et al. [79] & One influencer: the variety of partners in a platform's network \\
\hline Rossolini et al. [80] & $\begin{array}{l}\text { Three communication strategies: (1) message framing, (2) green emphasis, (3) } \\
\text { quantitative goals }\end{array}$ \\
\hline dos Santos Felipe et al. [81] & $\begin{array}{l}\text { Three elements: (1) longer exposure times, (2) a larger number of supporters, (3) a } \\
\text { higher volume of rewards }\end{array}$ \\
\hline Hsieh \& Vu [82] & Macroeconomic element: economic policy uncertainty \\
\hline Shim \& Lee [83] & Two influencers: (1) size of the social group, (2) perceived social presence \\
\hline Jeong \& Kim [84] & Product value: (1) design, (2) price, (3) storytelling, (4) brand, (5) functional factors \\
\hline Sherman \& Axelrad [85] & One push: desire for fulfillment in life \\
\hline Ryoba et al. [86]; Yin et al. [87] & Dynamic interaction: ongoing communication with the crowd \\
\hline de Larrea et al. [88] & $\begin{array}{l}\text { Three factors: (1) community orientation, (2) images, (3) frequent communication } \\
\text { with funders }\end{array}$ \\
\hline Belleflamme et al. [89] & Funding context: (1) funding of goods, (2) resources, (3) services, (4) social problems \\
\hline
\end{tabular}

\subsection{Hypotheses Based on the Literature}

Given the importance of the four mentioned factors (green product design, manufacturing, marketing, and the green diversified context) in the product life cycle for green products, as well as their value to sustainability, this study considers the following hypothesis.

Hypothesis 1. Green product design, manufacturing, marketing, and the green diversified context are the key factors for crowdfunding green products.

Among the four factors, the green diversified context is closely connected with the other factors. Considering the significant impact of contextual influences on crowdfunding success, this study raised the corresponding hypothesis. 
Hypothesis 2. The green diversified context is the most crucial factor in crowdfunding green products.

\section{Research Methods and Steps}

Compared with the two research objectives, this study mainly employs three research methods, in chronological order: (1) expert interviews, (2) a questionnaire, and (3) analytic hierarchy process (AHP) analysis.

\subsection{Expert Interviews}

To obtain a more objective hierarchical structure of key factors, this study adopted the research method of expert interviews to review and revise the structure.

\section{(1) Composition of Experts}

The expert group for this study consisted of five people, namely two experts from academia and three experts from industry. The academic experts were all professors of design with rich industry-university cooperation experience. Experts in industry were brand founders with significant practical experience, and their brand products had been crowdfunded successfully through crowdfunding platforms. The professional background and academic degrees held by the five experts are shown in Table 3.

Table 3. Composition of experts.

\begin{tabular}{cccc}
\hline Code & Experts & Background & Profession \\
\hline 01 & Manager Y & Brand founder & $\begin{array}{c}\text { Sponsor of crowdfunding (e.g., recycle } \\
\text { package) }\end{array}$ \\
02 & Manager H & Brand founder & $\begin{array}{c}\text { Sponsor of crowdfunding (e.g., tin straw) } \\
\text { Sponsor of crowdfunding (e.g., beverage cup, } \\
\text { lunch box) }\end{array}$ \\
03 & Manager W & Brand founder & $\begin{array}{c}\text { Professor in the School of Design, National } \\
\text { Yunlin University of Science \& Technology }\end{array}$ \\
04 & Professor T & $\begin{array}{c}\text { Expert in green design, creative design, and } \\
\text { lifestyle design }\end{array}$ \\
05 & Professor D & $\begin{array}{c}\text { Professor in the School of Design, National } \\
\text { Yunlin University of Science \& Technology }\end{array}$ & $\begin{array}{c}\text { Expert in brands, the craft economy, and } \\
\text { creative industry }\end{array}$ \\
\hline
\end{tabular}

\section{(2) Interview Process}

The expert interviews had three steps. (1) Expert preliminary review: After the preliminary construction of the hierarchical structure of key factors, five experts used their own experience and knowledge accumulation to check the key factors and the internal structure of the preliminary construction of the hierarchy, offering suggestions for modification. (2) Expert supplement: To improve the integrity of the factor hierarchy, a semi-structured interview was used to collect information and achieve information saturation. (3) Expert review: Experts reviewed the preliminary factor hierarchy again, finally delineating the hierarchy.

\subsection{Questionnaire}

To test the preliminary hierarchical structure of key factors and provide data support for the subsequent weight ranking of internal factors, this study adopted the research method of a questionnaire survey.

\section{(1) Questionnaire Design}

The questionnaire comprised two parts. The first part captured the subjects' basic information, including gender (male/female), age (18-29 and 30-39 years old), education level (undergraduate or postgraduate and above), and the frequency of crowdfunding browsing for green products per month (1-2,3-5, and 6 times or above). The second part captured the weight ranking of key factors, including the hierarchical structure description of key factors and the importance ranking of the first-level key factors. In addition, a 
weight comparison of first-level key factors was captured, as well as an importance ranking and a weight comparison of second-level key factors. Among these factors, the "key factor hierarchy explanation" included an evaluation scale explanation, as well as firstand second-level factor explanations. Exemplars and rules for answering the questions included "order of importance of first-level key factors," "weight comparison of first-level key factors," "order of importance of second-level key factors," and "weight comparison of second-level key factors."

\section{(2) Issuing and Receiving Questionnaires}

The questionnaire was distributed twice. The first (pretest) was used to test the reliability and validity of the survey and revise the questionnaire, and the second was used for formal distribution and obtaining the resulting statistics.

The questionnaire was directly distributed to green products' followers in targeted groups. People in these groups have experience financing green innovations on crowdfunding platforms, and they have formed certain social circles, which provide a reachable channel to contact.

After contacting the targeted groups through social media, this study recruited the required voluntary participants. The pretest and formal questionnaires were sent to them by e-mail. Participants were required to send the fully completed questionnaire back.

\subsection{AHP Analysis}

To obtain the internal weight order of key factors, this study adopted the AHP analysis method. The AHP method is mainly used in the case of uncertainty, through group discussion, to gather the opinions of experts, scholars, and participants. Then, the method is used to evaluate and summarize complex and lengthy decision-making problems, simplifying them into the focus of hierarchical analysis, and then comparing the problems in pairs [90]. Finally, according to the weight of the results, the ranking is obtained as a decision reference. AHP not only solves complex decision-making problems with the help of expert opinion but also determines the relative weight of each influencing factor through a comparison matrix and feature vector [91].

\section{(1) Application Process}

This study adopted the AHP method through seven steps. (1) Identify the problem: Understand the problem in detail, include factors that might affect the problem in the study, and define the scope of the problem clearly. (2) List all the factors related to the problem: List the factors related to the problem through literature collection, expert interviews, and other methods. (3) Establish a hierarchical structure: Draft a preliminary hierarchical structure of key factors. (4) Questionnaire design and survey: Compare factors at each level in pairs according to the evaluation criteria of factors at the upper level. (5) Establish a pairwise comparison matrix: The factor values of a pairwise comparison matrix are obtained from the results of the previous step, and the measured judgment values are geometrically averaged to establish a pairwise comparison matrix. (6) Calculate the priority vector and maximum eigenvalue: After the pairwise comparison matrix is obtained, obtain the eigenvector and calculate the priority vector value wi (priority vector) according to this eigenvector. (7) Calculate the indicator consistency: To determine the suitability of the questionnaire content, carry out consistency tests on the consistency index (C.I.) and consistency ratio (C.R.), which must both be less than 0.1 ; otherwise, the consistency of hierarchical factors will be problematic, and the consistency analysis of all factors must be performed again [90].

\section{(2) Evaluation Scale}

This study used the evaluation scale division of AHP to assign corresponding evaluation scale values from a nominal scale of 1 to 9 , where 1 is equal importance; 3 is moderate importance; 5 is essential/strong importance; 7 is very/strong importance; 9 is extreme 
importance; and 2, 4, 6, and 8 are compromise values between adjacent scales. On a scale of 1 to 9 , participants were asked to rate each of the paired comparison factors.

\section{Results}

Corresponding to the research objectives, the results of this study are presented in three parts. First, statistics of samples are presented. Then, this study offers the results of constructing the key factor hierarchy. Last, the ranking results of weights within the hierarchy are presented.

\subsection{Sample Statistics}

In the pretest, a total of 20 questionnaires were sent out, 20 were received, and 20 were valid. In the formal test, a total of 30 questionnaires were sent out, 26 were received, and 23 were valid. The samples met the requirements for AHP analysis.

The final data were based on the 23 valid samples. Regarding gender, most were female (17 in number), accounting for nearly $74 \%$ of the sample. For age, most participants were young people aged between 18 and 29 years (22 in number). For the education level, most participants were undergraduates (17 in number), accounting for nearly $74 \%$. Regarding the frequency of crowdfunding browsing, most participants (14 in number) had only 1-2 times per month (61\%), followed by a frequency of $3-5$ times (30\%), and 6 times or above $(9 \%)$.

\subsection{Establishing the Hierarchy of Key Factors}

The establishment of the hierarchical framework of this study consisted of five stages: (1) data consolidation, (2) expert review, (3) preliminary framework revision, (4) re-framework revision, and (5) confirmation framework. The following are the results of the five stages.

\subsubsection{Data Consolidation}

First, from the literature and the network, the hierarchical structure of factors was initially drawn based on keywords, including four first-level (primary) factors (the theoretical level of life cycle) and 24 s-level (secondary) factors (implementation level of public demand). Factors of the same level were independent, and second-level factors were subordinate to first-level factors. The four first-level factors were as follows: (1) green product design, (2) green product manufacturing, (3) green product marketing, and (4) the green diversified context.

- Among the factors, "green product design" included six secondary factors: (1) green innovative commodity development, (2) low production energy consumption, (3) simplified packaging or no packaging, (4) safe and non-toxic material, (5) recyclable, and (6) life cycle assessment.

- "Green product manufacturing" included six secondary factors: (1) choose green factories and logistics, (2) fundraising page of the cooperative factory is open and transparent, (3) product quality control, (4) delivery is on time, (5) inspection and certification, and (6) commodity verifying period and warranty service.

- "Green product marketing" contained nine secondary factors: (1) build a green brand story, (2) crowdfunding schedule is listed in full, (3) keep crowd fundraising progress updated, (4) capital flows become transparent, (5) establish a community interactive communication platform, (6) donate a portion of the proceeds to the community, (7) create more environmentally friendly mechanisms, (8) cooperate with green public welfare groups and fundraising e-commerce brands, and (9) fundraising pages and videos show the importance of green consumption.

- Finally, the "green diversified context" included three secondary factors: (1) implementation of a plastic limit policy, (2) vigorous development of green trends, and (3) improvement of public awareness of environmental protection. 


\subsubsection{Hierarchical Framework of Experts' Preliminary Review Factors}

Five experts were invited to review the hierarchical structure of the factors initially drawn up, and the hierarchical structure was corrected based on the theoretical and practical experience accumulated by the experts in their respective fields. During the audit process, experts' insights on the preliminary hierarchical architecture were obtained through semi-structured interviews. Experts agreed to the following: (1) Regarding "green product design," products need to be innovative, safe, and durable to increase consumers' willingness to buy. (2) For "green manufacturing," the process requires strict quality management to meet consumer expectations. (3) In the "green product marketing" process, word-ofmouth marketing is key. In addition to their own brand value, it can also promote joint marketing integration of green social forces. (4) Regarding the "green diversified context," in addition to environmental protection consciousness among people, the implementation of the plastic limit is an important factor encouraging consumers to increase purchases of green goods. (5) The first-level factor "green product distribution" should be added, making the structure of first-level factors more complete, and (6) secondary factors need to be revised from the perspective of consumers' cognition.

\subsubsection{Preliminary Revised Factor Hierarchy}

After the revision of second-level factors and the expert review, the hierarchy structure was adjusted in three aspects. (1) A first-level factor "green product distribution" and three corresponding second-level factors were added: constantly optimized distribution system, delivering products on time, and availed energy-saving and environmentally friendly transportation. (2) Based on the cognition of consumers, some of the secondary factors were added or deleted. (3) The wording of the secondary factors was polished to make the expression clearer and more straightforward. After preliminary revision, there were 5 primary factors and 25 secondary factors in the construct.

\subsubsection{Modify the Factor Hierarchy Structure}

Twenty volunteers were invited to conduct a pretest, and this study used AHP for data analysis. Expert Choice software was used to verify the consistency of the evaluation process. We found that the consistency index (C.I.) of the 20 samples on the first-level factors was generally greater than 0.1 (as shown in Table 4), which showed that the judgment of the volunteers in the evaluation process was inconsistent. Thus, the factor framework needed to be modified.

Referring to the pretest result, expert review, and modifying factors for the hierarchical structure, the resulting actions were as follows: (1) secondary factors with a high wi value that were closely linked to consumers were kept; (2) secondary factors that had a low wi value but were closely linked to consumers were also kept; (3) secondary factors with overlapping meanings were combined; and (4) secondary factors with low wi values or with general expressions were deleted. The number of secondary factors was thus reduced from 25 to 19 (Table 5).

\subsubsection{Confirm the Factor Hierarchy}

After two revisions, the final factor hierarchy consisted of 5 primary and 19 secondary factors. First-level factors included the following: green product design, green product manufacturing, green product marketing, green diversified context, and green product distribution. The original four factors remained. Thus, Hypothesis 1 was supported.

Among the five first-level factors, four factors (green product design, green product manufacturing, green product marketing, green diversified context) included four secondlevel factors, while "green transportation and distribution" included three second-level factors. The final factor-level architecture content and encoding are shown in Table 6. The results showed that if any green products on crowdfunding platforms fit the 24 factors, the 23 participants would make the decision to finance these green innovations. 
Table 4. Pretest results.

\begin{tabular}{cccccc}
\hline Sample & \multicolumn{5}{c}{ C.I. } \\
\cline { 2 - 6 } & $\begin{array}{c}\text { Green Product } \\
\text { Design }\end{array}$ & $\begin{array}{c}\text { Green Product } \\
\text { Manufacturing }\end{array}$ & $\begin{array}{c}\text { Green Product } \\
\text { Marketing }\end{array}$ & $\begin{array}{c}\text { Green Diversified } \\
\text { Context }\end{array}$ & $\begin{array}{c}\text { Green Product } \\
\text { Distribution }\end{array}$ \\
\hline A-1 & 0.17 & 0.05 & 0.09 & 0.13 & 0.07 \\
A-2 & 0.44 & 0.50 & 1.01 & 0.53 & 0.44 \\
A-3 & 0.29 & 0.23 & 0.78 & 0.42 & 0.43 \\
A-4 & 0.19 & 0.65 & 1.01 & 0.53 & 0.50 \\
A-5 & 0.50 & 1.75 & 0.51 & 0.53 & 0.50 \\
A-6 & 0.23 & 0.13 & 0.40 & 0.06 & 0.29 \\
A-7 & 0.28 & 0.34 & 0.46 & 0.53 & 0.14 \\
A-8 & 0.20 & 0.01 & 0.17 & 0.42 & 0.77 \\
A-9 & 0.09 & 0.22 & 0.15 & 0.42 & 0.03 \\
A-10 & 0.26 & 0.13 & 0.18 & 0.13 & 0.11 \\
A-11 & 0.03 & 0.32 & 0.06 & 0.00 & 0.08 \\
A-12 & 0.23 & 0.39 & 0.36 & 0.13 & 0.04 \\
A-13 & 1.06 & 0.38 & 0.37 & 0.13 & 0.41 \\
A-14 & 0.21 & 0.33 & 0.42 & 0.28 & 0.36 \\
A-15 & 0.32 & 0.13 & 0.27 & 0.13 & 0.20 \\
A-16 & 0.25 & 1.01 & 0.68 & 0.13 & 0.40 \\
A-17 & 0.19 & 0.03 & 0.32 & 0.20 & 0.14 \\
A-18 & 0.29 & 0.25 & 0.14 & 0.17 & 0.33 \\
A-19 & 0.13 & 0.22 & 0.33 & 0.13 & \\
A-20 & 0.11 & 0.13 & 0.24 & & \\
\hline
\end{tabular}

Table 5. Second revision of the factor hierarchy.

\begin{tabular}{|c|c|c|c|}
\hline Primary Factors & Secondary Factors & Wi & Expert Opinions \\
\hline \multirow{5}{*}{ Green product design } & Product is innovative & 0.198 & Keep \\
\hline & Product is lightweight & 0.157 & Delete \\
\hline & Product material is safe and non-toxic & 0.285 & Keep \\
\hline & Product material is recyclable & 0.194 & Keep \\
\hline & Product life cycle is extended & 0.267 & Keep \\
\hline \multirow{5}{*}{$\begin{array}{l}\text { Green product } \\
\text { manufacturing }\end{array}$} & Product has low energy consumption for production & 0.183 & \multirow{2}{*}{$\begin{array}{l}\text { Combine as "product is } \\
\text { made in green factories" }\end{array}$} \\
\hline & Product is produced by reputable factories & 0.187 & \\
\hline & Product quality is guaranteed & 0.256 & Keep \\
\hline & Product has an inspection mark & 0.217 & Keep \\
\hline & Product packaging is streamlined & 0.157 & Keep \\
\hline \multirow{7}{*}{$\begin{array}{l}\text { Green product } \\
\text { marketing }\end{array}$} & Green brand story is built & 0.083 & Delete \\
\hline & Crowdfunding schedule is public & 0.120 & \multirow{2}{*}{$\begin{array}{l}\text { Combine as "crowdfunding } \\
\text { process is public" }\end{array}$} \\
\hline & Crowdfunding flows are public & 0.147 & \\
\hline & Interactive network platforms are built & 0.090 & Keep \\
\hline & Environmentally friendly mechanisms are established & 0.146 & Delete \\
\hline & Green social forces work closely together & 0.100 & Keep \\
\hline & Product green data are public & 0.202 & Keep \\
\hline
\end{tabular}


Table 5. Cont.

\begin{tabular}{cccc}
\hline Primary Factors & Secondary Factors & Wi & Expert Opinions \\
\hline \multirow{4}{*}{$\begin{array}{c}\text { Green diversified } \\
\text { context }\end{array}$} & Plastic limit policy is implemented & 0.149 & Keep \\
\cline { 2 - 4 } & Green design becomes a development trend & 0.135 & Keep \\
\cline { 2 - 4 } & Public awareness of environmental protection increases & 0.284 & Delete \\
\cline { 2 - 4 } & Green education is implemented in schools & 0.245 & Keep \\
\hline \multirow{2}{*}{$\begin{array}{c}\text { Green product } \\
\text { distribution }\end{array}$} & Product price is reasonable & 0.187 & Keep \\
\cline { 2 - 4 } & Product distribution system is continuously optimized & 0.413 & Keep \\
\cline { 2 - 4 } & Product is delivered on time & 0.384 & Keep \\
\hline
\end{tabular}

Table 6. Construct and contents of factor hierarchy.

\begin{tabular}{|c|c|c|c|}
\hline & Primary Factors & & Secondary Factors \\
\hline \multirow{4}{*}{ F1 } & \multirow{4}{*}{ Green product design } & F1-1 & Product is innovative \\
\hline & & F1-2 & Product material is safe and non-toxic \\
\hline & & F1-3 & Product material is recyclable \\
\hline & & F1-4 & Product life cycle is extended \\
\hline \multirow{4}{*}{$\mathrm{F} 2$} & \multirow{4}{*}{ Green product manufacturing } & F2-1 & Product is made in green factories \\
\hline & & $\mathrm{F} 2-2$ & Product quality is guaranteed \\
\hline & & $\mathrm{F} 2-3$ & Product has an inspection mark \\
\hline & & F2-4 & Product packaging is streamlined \\
\hline \multirow{4}{*}{ F3 } & \multirow{4}{*}{ Green product marketing } & F3-1 & Crowdfunding process is public \\
\hline & & F3-2 & Interactive network platforms are built \\
\hline & & F3-3 & Green social forces work closely together \\
\hline & & F3-4 & Product green data are public \\
\hline \multirow{4}{*}{$\mathrm{F} 4$} & \multirow{4}{*}{ Green diversified context } & F4-1 & Plastic limit policy is implemented \\
\hline & & F4-2 & Green design becomes a development trend \\
\hline & & F4-3 & Green education is implemented in schools \\
\hline & & F4-4 & Product price is reasonable \\
\hline \multirow{3}{*}{ F5 } & \multirow{3}{*}{ Green product distribution } & F5-1 & Product distribution system is continuously optimized \\
\hline & & F5-2 & Product is delivered on time \\
\hline & & F5-3 & Product transportation is energy conservative \\
\hline
\end{tabular}

\subsection{Internal Weight Ordering of Factor Hierarchy}

Expert Choice software was used to analyze the data received from these 23 questionnaires, and the internal weight row of factor hierarchy structure was obtained. The weight ranking results had the following three parts: (1) the weight ranking of first-level factors, (2) the weight ranking of second-level factors in first-level factors, and (3) the overall weight ranking of second-level factors.

\subsubsection{Weight Ranking of First-Level Factors}

The results of AHP analysis of five first-level factors show that C.I. values and C.R. values were both less than 0.1 (C.I. $=0.030$, C.R. $=0.027$ ), indicating that the subjects' judgment on the evaluation process of first-level factors was consistent.

The relative weight values of the five first-level factors (see Table 7), from large to small, were as follows: 0.349 (F4: green diversified context), 0.310 (F1: green product design), 0.201 (F3: green product marketing), 0.096 (F2: green product manufacturing), and 0.044 (F5: green product distribution). The findings indicate the influence of these five 
first-level factors on consumers' choice of green crowdfunding products from strong to weak were in the following order: green diversified context, green product design, green product marketing, green product manufacturing, and green product distribution. "Green diversified context" ranked first. Thus, Hypothesis 2 was supported.

Table 7. Priority ranking of primary factors.

\begin{tabular}{cccccccc}
\hline Primary Factor & F1 & F2 & F3 & F4 & F5 & Wi & Ranking \\
\hline F1 & - & 4.110 & 1.854 & 1.392 & 5.935 & 0.310 & 2 \\
F2 & & & 2.810 & 3.907 & 3.652 & 0.096 & 4 \\
F3 & & & 1.945 & 4.920 & 0.201 & 3 \\
F4 & & & & 5.511 & 0.349 & 1 \\
F5 & & & & & & 0.044 & 5 \\
\hline
\end{tabular}

4.3.2. Weight Ranking of Second-Level Factors among First-level Factors

(1) Weight Ranking of Secondary Factors in "Green Product Design"

The AHP analysis results of the four secondary factors included in "green product design" show that C.I. values and C.R. values were all less than 0.1 (C.I. $=0.010$, C.R. $=0.011$ ), indicating that the subjects' judgment on the evaluation process of the four secondary factors was consistent.

The relative weight values of the four second-level factors (see Table 8), from large to small, were as follows: 0.364 (F1-2: product materials are safe and nontoxic), 0.240 (F1-4: product life-cycle extension), 0.226 (F1-3: product materials can be recycled), and 0.170 (F1-1: product is innovative). The findings indicate the importance of these four secondary factors to the first-level factor "green product design," in order from strong to weak: product material is safe and nontoxic, product life cycle is extended, product material can be recycled, and the product is innovative.

Table 8. Ranking of secondary factors in "green product design".

\begin{tabular}{ccccccc}
\hline & F1-1 & F1-2 & F1-3 & F1-4 & Wi & Ranking \\
\hline F1-1 & - & 0.572 & 0.608 & 0.705 & 0.170 & 4 \\
F1-2 & & & 1.848 & 1.607 & 0.364 & 1 \\
F1-3 & & & & 0.872 & 0.226 & 3 \\
F1-4 & & & & & 0.240 & 2 \\
\hline
\end{tabular}

(2) Weight Ranking of Secondary Factors in "Green Product Manufacturing"

AHP analysis results of four secondary factors included in "green product manufacturing" show that C.I. values and C.R. values were both less than 0.1 (C.I. $=0.003$, C.R. $=0.004)$, indicating consistent judgment for the subjects on the evaluation process of the four secondary factors.

The relative weight values of the four second-level factors (see Table 9), from large to small, were as follows: 0.330 (F2-3: products have an inspection mark), 0.284 (F2-2: product quality is guaranteed), 0.240 (F2-1: products are made by a green factory), and 0.146 (F2-4: product packaging is simplified). The findings indicate the importance of these four secondary factors to the first-level factor "green product manufacturing," from strong to weak, in descending order: product has an inspection quality mark, the product quality is guaranteed, the product is made by a green factory, and the product packaging is simplified. 
Table 9. Ranking of secondary factors in "green product manufacturing".

\begin{tabular}{ccccccc}
\hline & F2-1 & F2-2 & F2-3 & F2-4 & Wi & Ranking \\
\hline F2-1 & - & 0.808 & 0.731 & 1.723 & 0.240 & 3 \\
F2-2 & & & 0.932 & 1.699 & 0.284 & 2 \\
F2-3 & & & & 2.472 & 0.330 & 1 \\
F2-4 & & & & & 0.146 & 4 \\
\hline
\end{tabular}

(3) Weight Ranking of Secondary Factors in "Green Product Marketing"

AHP analysis results of the four secondary factors included in "green product marketing" show that C.I. values and C.R. values were both less than 0.1 (C.I. $=0.003$, C.R. $=0.004$ ), indicating that the subjects' judgment on the evaluation process of the four secondary factors was consistent.

The relative weight values of the four second-level factors (see Table 10), from large to small, were as follows: 0.408 (F3-1: crowdfunding process is public), 0.319 (F3-4: product green data are public), 0.168 (F3-2: interactive network platforms are built), and 0.105 (F3-3: green social forces work closely together). The findings indicate the importance of these four secondary factors to the first-level factor "green product marketing," in order from strong to weak: the crowdfunding process is public, the product green data are public, the interactive network platforms are built, and the green social forces work closely together.

Table 10. Ranking of secondary factors in "green product marketing".

\begin{tabular}{ccccccc}
\hline & F3-1 & F3-2 & F3-3 & F3-4 & Wi & Ranking \\
\hline F3-1 & - & 2.356 & 3.855 & 1.332 & 0.408 & 1 \\
F3-2 & & & 1.607 & 0.514 & 0.168 & 3 \\
F3-3 & & & & 0.325 & 0.105 & 4 \\
F3-4 & & & & & 0.319 & 2 \\
\hline
\end{tabular}

(4) Weight Ranking of Secondary Factors in the "Green Diversified Context"

The AHP analysis results of the four secondary factors included in "green diversified context" show that C.I. values and C.R. values were both less than 0.1 (C.I. $=0.004$, C.R. $=0.005)$, indicating consistent subjects' judgment on the evaluation process of the four secondary factors.

The relative weight values of the four second-level factors (see Table 11), from large to small, were as follows: 0.265 (F4-4: product price is reasonable), 0.258 (F4-2: green design becoming a development trend), 0.247 (F4-1: implementation of plastic restriction policy), and 0.229 (F4-3: implementation of green education in schools). The findings indicate the significance of these four secondary factors to the first-level factor "green diversified context," from strong to weak, in descending order: The product price is reasonable, green design becomes a development trend, the implementation of a plastic policy, and the implementation of green education in schools.

Table 11. Ranking of secondary factors in the "green diversified context".

\begin{tabular}{ccccccc}
\hline & F4-1 & F4-2 & F4-3 & F4-4 & Wi & Ranking \\
\hline F4-1 & - & 1.038 & 0.936 & 0.981 & 0.247 & 3 \\
F4-2 & & & 1.274 & 0.932 & 0.258 & 2 \\
F4-3 & & & & 0.847 & 0.229 & 4 \\
F4-4 & & & & & 0.265 & 1 \\
\hline
\end{tabular}


(5) Weight Ranking of Secondary Factors in "Green Product Distribution"

AHP analysis results of three secondary factors included in "green product distribution" show that C.I. values and C.R. values were all less than 0.1 (C.I. $=0.009$, C.R. $=0.015$ ), indicating that the subjects' judgment on the evaluation process of these three secondary factors was consistent.

The relative weight values of these three second-level factors (see Table 12), from large to small, were as follows: 0.464 (F5-1: distribution system is constantly optimized), 0.380 (F5-2: products are delivered on time), and 0.155 (F5-3: product transportation is energy conservative). The findings indicate the importance of these three second-level factors to the first-level factor "green product distribution," from strong to weak, in descending order: the distribution system is constantly optimized, products are delivered on time, and the product transportation is energy conservative.

Table 12. Ranking of secondary factors in "green product distribution".

\begin{tabular}{cccccc}
\hline & F5-1 & F5-2 & F5-3 & Wi & Ranking \\
\hline F5-1 & - & 1.184 & 3.083 & 0.464 & 1 \\
F5-2 & & & 2.374 & 0.380 & 2 \\
F5-3 & & & & 0.155 & 3 \\
\hline
\end{tabular}

\subsubsection{Overall Weight Ranking of Secondary Factors}

The 19 secondary factors were ranked in descending order according to the overall weight value, and the order is listed in Table 13.

Table 13. Priority ranking of all factors.

\begin{tabular}{cccc}
\hline Ranking & Wi & Secondary Factors & Primary Factors \\
\hline 1 & 0.113 & Product material is safe and non-toxic & Green product design \\
2 & 0.092 & Product price is reasonable & Green diversified context \\
3 & 0.090 & Green design becomes a development trend & Green diversified context \\
4 & 0.086 & Plastic limit policy is implemented & Green diversified context \\
5 & 0.082 & Crowdfunding process is public & Green product marketing \\
6 & 0.080 & Green education is implemented in schools & Green diversified context \\
7 & 0.074 & Product life cycle is extended & Green product design \\
8 & 0.070 & Product material is recyclable & Green product design \\
9 & 0.064 & Product green data are public & Green product marketing \\
10 & 0.053 & Product is innovative & Green product design \\
11 & 0.034 & Interactive network platforms are built & Green product marketing \\
12 & 0.032 & Product has inspection mark & Green product manufacturing \\
13 & 0.027 & Product quality is guaranteed & Green product manufacturing \\
14 & 0.023 & Product is made in green factories & Green product manufacturing \\
15 & 0.021 & Green social forces work closely together & Green product marketing \\
16 & 0.020 & Product distribution system is continuously optimized & Green product distribution \\
17 & 0.017 & Product is delivered on time & Green product distribution \\
18 & 0.014 & Product packaging is streamlined & Green product manufacturing \\
19 & 0.007 & Product transportation is energy conservative & Green product distribution \\
\hline
\end{tabular}

Among the top five secondary factors, three were subordinate to "green diversified context," one was subordinate to "green product design," and one was subordinate to "green product marketing." Among the top 10 s-level factors, four were subordinate to "green product design," four were subordinate to "green diversified context," and two were subordinate to "green product marketing." 


\section{Discussion}

This section examines the following dimensions: (1) limitations of the study, (2) future research directions, (3) theoretical contributions, and (4) practical contributions.

\subsection{Limitations of the Study}

\section{(1) Construct Limitations}

This study established a new construct from the targeted aspects of product life cycle and public demand perspectives, leading to content coverage limitations for the construct. Specifically, the five primary factors in the construct are derived from a product life cycle perspective, while the 19 secondary factors are based on preferences and requirements of public demand. Therefore, the construct in this study provided insights for only these aspects to enterprises that intend to obtain theoretical support before launching new green products on crowdfunding platforms.

In addition, to aid decision-making for participants, this study applied a specific piece of software (Expert Choice) when there were many factors. However, decision-making in this study is only a virtual action rather than a real funding action because most of the participants are potential funders. Specifically, participants were required to imagine what factors would influence their decision-making if they were about to finance green products on crowdfunding platforms. Therefore, the feedback from these participants is the prediction of crowdfunding green products based on their recognition of green products, as well as their preferences. In other words, if green products on crowdfunding platforms fit the 24 factors, these participants are very likely to finance these green innovations. For further confirmation, future studies could invite real funders with successful crowdfunding experience to test the 24 -factor construct.

\section{(2) Sample Limitations}

Participants in this study, whose feedback is partly the source of public demand toward crowdfunding success, were young people with higher education levels in Taiwan, and participants' geographic, educational, and age backgrounds may determine their recognition and perspective toward crowdfunding success. The construct and priority ranking of the factors affecting crowdfunding for green products are based on well-educated young people's preferences and expectations. Thus, the application of this study may only be applicable to crowdfunding with young people as the target group. However, this result adapts to the trend of crowdfunding situations, since investors in crowdfunding tend to be in the younger age group [92].

Another sample limitation is the sample size. Although acceptable for analysis, the final result of 23 potential funders is still a relatively small sample for AHP. This study attempted to target more samples, but the willingness of green products' followers to participate as volunteers in this research was not very high, partly because it is complex and time consuming to fill in the questionnaire for AHP analysis.

\subsection{Future Research Direction}

\section{(1) Update Contents of Construct}

Social impacts hugely influence factors of crowdfunding success; therefore, the construct in this study should be updated in future research to keep up with social developments. This trend could be anticipated by the research result that the green diversified context was the most influential primary factor in the final construct, which is by nature a dynamic factor. Furthermore, public demand for safety and nontoxic products ranked first among all secondary factors, which was in accordance with people's safety expectations and appealed to the current pandemic situation.

\section{(2) Amplify the Sample Category and Size}

Green products are not only for young people but should serve different age groups. Therefore, the sample category could be amplified in future studies. For example, since an 
aging population is a global phenomenon, studies surrounding green products for elderly people are valuable, and factors for crowdfunding success are worthy of study. Moreover, this study is conducted in Taiwan-participants' feedback is naturally limited by their cultural background. Hence, future studies could amplify the sample category by involving participants from various cultural backgrounds.

The sample size should also be expanded. One way to achieve this aim would be to cooperate with professional survey organizations to obtain more samples; another would involve working with green product companies to collect data as preliminary market research.

\subsection{Theoretical Contributions}

\section{(1) Contribution to Product Life Cycle Theory}

This study contributes to product life cycle theory by extending the boundary, as well as enriching the contents of the product life cycle. As for extending the theoretical boundary, this study put a relatively abstract "product life cycle" concept into the specific and challenging context of a crowdfunding situation, amplifying the construct of product life cycle from the basic "material, production, and recycle" model [93] to multidimensional perspectives of "design, manufacturing, marketing, context, and distribution." Further, "Green products" are better defined for reward-based crowdfunding platforms; thus, this study extends the application of life cycle theory into the crowdfunding business domain.

Regarding the enrichment of theoretical content, this study rejuvenated items in the product life cycle by cementing multiple factors related to crowdfunding. Specifically, the extracted 19 secondary factors supplement the product life cycle theory through five primary factors (green product design, manufacturing, marketing, distribution, and the green diversified context). For example, the most influential primary factor "green diversified context" in this study was solidified with four secondary factors from political (plastic limit policy is implemented), environmental (green design becomes a development trend), educational (green education is implemented in schools), and financial (product price is reasonable) perspectives.

\section{(2) Contribution to Crowdfunding Theory}

This study contributes to crowdfunding theory by providing new measurements as well as studying crowdfunding from a new perspective. For new measurements, this study summarized 5 primary and 19 secondary factors relating to crowdfunding success for green products and established the inherent hierarchy. Thus, the extracted construct could be seen as a dimensional measurement covering social, environmental, and economic considerations. Compared with previous measurements, the construct echoes Hsieh et al.'s [32] environmental and social aspects of measurements, Jeong et al.'s [84] product value measurements (including design, price, storytelling, and branding), and Cosma et al.'s [79] measurements covering a variety of partners.

Regarding a new perspective, this study examined two views of green product life cycle and public demand as starting points to conduct a survey. The initial four key elements of green products (green product design, manufacturing, marketing, and the green diversified context) were established based on the life cycle perspective, and the questionnaire was designed based on public demand. Furthermore, the final result was still in accordance with these two aspects; 5 primary factors of the final construct were based on the product life cycle perspective, while 19 secondary factors were based on the public demand perspective. Therefore, the measurements combined with this perspective enhance the methodology study for crowdfunding theory.

\subsection{Practical Contributions}

(1) Improve Crowdfunding Efficiency

The construct and priority ranking in this study are aimed at improving crowdfunding efficiency for green products. When launching a green product on a crowdfunding platform, 
the fate of the green product and the success possibilities of crowdfunding are uncertain in a particular period. Furthermore, if "green" is merely used as a gimmick to attract public attention, the probability of success for the campaign will be weak [17]. The uncertainty of the market response and a poor method of attracting public attention are two problems facing crowdfunding for green products, thus decreasing crowdfunding efficiency.

Responding to these issues, this study developed a construct and further tested its reliability to improve crowdfunding efficiency. Specifically, the construct is composed of 5 primary and 19 secondary factors, which embrace social, economic, environmental, and educational considerations in the face of crowdfunding challenges. The 5 primary factors are pillars of the final construct, and the 19 secondary factors elaborate possible actions for the primary factors. All these factors were intended to systematically present the possible solutions contributing to related challenges in crowdfunding uncertainties and offer a clear description of "green," thus improving crowdfunding efficiency for green products.

\section{(2) Promote Green Supply Chain Management}

This study not only contributes to crowdfunding efficiency but also to the green supply chain behind crowdfunding. Green supply chain management calls for circular supply chains, and the construct in this study is beneficial to different parties along the circular supply chains of green products, including crowdfunding platforms, enterprises, and consumers. Specifically, the factors in the construct could function as criteria for crowdfunding platforms to select potential green products, for enterprises to better design green products as references and make timely adjustments before launching, and for consumers to quickly understand the "green" of products to make supporting actions through effective key messages on crowdfunding platforms.

Furthermore, the construct could contribute to the dynamic balance of the supply and demand sides in the supply chain by improving crowdfunding efficiency, as mentioned above, because the success of online crowdfunding is a strong signal from the demand side that the order and financial support is guaranteed. Consequently, the supply side would focus on production and manufacturing without worrying too much about the obstacles in sales, particularly in the current pandemic context. These factors contribute to green supply chain management.

\section{Conclusions and Suggestions}

\subsection{Conclusions}

Crowdfunding for green products is a topic worthy of study, echoing the trend toward economic, social, and environmental sustainability, particularly when green products are facing production and promotion challenges under the current pandemic. As a medium to bridge the demand and supply sides, crowdfunding is reputable for funding ecological projects but faces limited theoretical investigations regarding the funding of green products.

To promote crowdfunding efficiency, this study built a construct for the crowdfunding success of green products and sorted the priority ranking of the relevant factors. Complicated methods and multistep processes were conducted to explore and test the construct, including expert interviews, questionnaire surveys, and AHP analyses.

Based on the study perspective of product life cycle and public demand, the final construct comprises 24 factors in two hierarchies, which contribute to funders' decision-making regarding financing green products on crowdfunding platforms. Specifically, 5 primary and 19 secondary factors were identified. Regarding the significance to crowdfunding success among the primary factors, "green diversified context" ranked first, followed by "green product design," "green product marketing," "green product manufacturing," and "green product distribution." For the contribution of the secondary factors, the top five concerns are the safety of product material, a reasonable price, green design trends, policy restrictions, and the transparency of the crowdfunding process.

Among the five primary factors contributing to the crowdfunding success of green products, "green diversified context" was the most influential, agreeing with the results of previous studies because "context"-related factors were found to be crucial to crowd- 
funding success socially $[32,78,79,83,86-89]$, environmentally $[32,80]$, politically [82], and economically [82]. Further, the value of a green-diversified context perceived by funders also echoes the findings of previous studies in terms of the general consent regarding the importance of environmental, economic, and social impacts to sustainability $[58,66]$. Among the 19 secondary factors contributing to the crowdfunding success of green products, "product material is safe and non-toxic" and "product price is reasonable" were the top 2 most important, agreeing with Chen's study [40], which found that green materials should follow basic principles, such as non-toxic, harmless, and best economy. Furthermore, "green design becomes a development trend" ranked in the top 3, echoing previous studies determining that public demand for green products is trending [50,71].

By building a construct and finding priority rankings of factors affecting the crowdfunding of green products, this study theoretically contributes to product life cycle and crowdfunding theory. Practical contributions were identified for crowdfunding efficiency and green supply chain sustainability. Reflecting on the study limitations, this work suggests updating the contents of the construct and amplifying sample categories for further theoretical investigation.

\subsection{Suggestions}

Reflecting on this research, the purpose was clear and focused, the research methods were relatively straightforward, and the results fit the hypotheses and were consistent with previous studies. However, the depth of analysis was limited for two reasons. First, the topic of this research has a large domain of coverage owing to the complicated nature of crowdfunding, including environmental, economic, and social considerations, which makes it challenging to discuss each related part based on our team's limited academic background. Second, the abstracted factors were mainly based on the literature review, and there is a natural gap between discovered theoretical knowledge and updated crowdfunding reality, thus limiting the practical perspective of analysis.

This study was preliminary theoretical research into crowdfunding for green products. Future works should take a reasonable application of the results and conduct further research into the practical side of crowdfunding for green products. The construct has been theoretically analyzed and statistically tested in this study, but its value can only be manifested by implementation in real processes during crowdfunding. Future researchers could investigate the effectiveness of this construct for specific parties, such as crowdfunding platforms, production enterprises, and designers for green products. Further modifications and updates to the construct with timely and real feedback can contribute to crowdfunding efficiency, green supply chain management, and the sustainability of green products.

Author Contributions: All authors contributed to the paper. X.-Y.Z. wrote the manuscript; J.-C.T. and S.G. supervised the writing; T.-H.L. collected data; M.Y. gave suggestions. All authors have read and agreed to the published version of the manuscript.

Funding: This research was funded by Zhejiang Sci-Tech University (Grant No. 20082331-Y), the Ministry of Education of China (Grant No.202101389014), the China Postdoctoral Science Foundation (Grant No. 2021M702899), and Fashion Design Talents' Introduction and Training Fund (Project Name: Study on "san sheng rong he" Design Theory).

Institutional Review Board Statement: Not applicable.

Informed Consent Statement: Not applicable.

Data Availability Statement: The data presented in this study are available within the paper.

Conflicts of Interest: The authors declare no conflict of interest. 


\section{References}

1. Joowon, J.; Cho, S.Y. Interaction effects of willingness to pay environmental protection expenditures in the relationship between changes in environmental consciousness and environment-friendly consumption behavior before and after the COVID-19 pandemic. Kor. J. Environ. Educ. 2021, 34, 210-227.

2. Leow, N.X.; Krishnaswamy, J. Smart cities need environmental consciousness and more social responsibilities as an outcome of COVID-19-Reflections from urban road commuters. Foresight 2021, 27, 1463-6689. [CrossRef]

3. Mdivani, M.; Alexandrova, E. Pandemic in the Context of on Environmental Consciousness. Exp. Psychol. 2021, 14, 67-78. [CrossRef]

4. Sun, X.; Su, W.; Guo, X.; Tian, Z. The Impact of Awe Induced by COVID-19 Pandemic on Green Consumption Behavior in China. Int. J. Environ. Res. Public Heal. 2021, 18, 543. [CrossRef] [PubMed]

5. Fattah, F.A.M.A.; Dahleez, K.A.; Mohamed, A.H.H.; Okour, M.K.; AL Alawi, A.M.M. Public health awareness: Knowledge, attitude and behaviors of the public on health risks during COVID-19 pandemic in sultanate of Oman. Glob. Knowl. Mem. Commun. 2021, 71, 27-51. [CrossRef]

6. Ali, Q.; Parveen, S.; Yaacob, H.; Zaini, Z.; Sarbini, N.A. COVID-19 and dynamics of environmental awareness, sustainable consumption and social responsibility in Malaysia. Environ. Sci. Pollut. Res. 2021, 28, 56199-56218. [CrossRef] [PubMed]

7. Tran, L.T.T. Managing the effectiveness of e-commerce platforms in a pandemic. J. Retail. Consum. Serv. 2020, 58, 102287. [CrossRef]

8. Severo, E.A.; De Guimarães, J.C.F.; Dellarmelin, M.L. Impact of the COVID-19 pandemic on environmental awareness, sustainable consumption and social responsibility: Evidence from generations in Brazil and Portugal. J. Clean. Prod. 2020, 286, 124947. [CrossRef] [PubMed]

9. Mehta, P.; Chahal, H.S. Consumer attitude towards green products: Revisiting the profile of green consumers using segmentation approach. Manag. Environ. Qual. Int. J. 2021, 32, 902-928. [CrossRef]

10. Akhtar, R.; Sultana, S.; Masud, M.M.; Jafrin, N.; Al-Mamun, A. Consumers' environmental ethics, willingness, and green consumerism between lower and higher income groups. Resour. Conserv. Recycl. 2020, 168, 105274. [CrossRef]

11. Li, G.; Yang, L.; Zhang, B.; Li, X.; Chen, F. How do environmental values impact green product purchase intention? The moderating role of green trust. Environ. Sci. Pollut. Res. 2021, 28, 46020-46034. [CrossRef] [PubMed]

12. Commission of the European Communities, Green Paper on Integrated Product Policy. 2001. Available online: https://eur-lex. europa.eu/legal-content/EN/TXT/?uri=CELEX\%3A52001DC0068\&qid=1643722237685 (accessed on 1 February 2022).

13. Zhou, J.-G.; Li, L.-L.; Tseng, M.-L.; Ahmed, A.; Shang, Z.-X. A novel green design method using electrical products reliability assessment to improve resource utilization. J. Ind. Prod. Eng. 2021, 38, 561-572. [CrossRef]

14. Chen, Y.-S.; Chang, T.-W.; Lin, C.-Y.; Lai, P.-Y.; Wang, K.-H. The Influence of Proactive Green Innovation and Reactive Green Innovation on Green Product Development Performance: The Mediation Role of Green Creativity. Sustainability $2016,8,966$. [CrossRef]

15. United Nations. Sustainable Development Goals. 2021. Available online: https://www.un.org/sustainabledevelopment/ (accessed on 8 August 2021).

16. Yang, M.H.; Chen, H.; Long, R.Y.; Wang, Y.J.; Hou, C.M.; Liu, B. Will the public pay for green products? Based on analysis of the influencing factors for Chinese's public willingness to pay a pricepremium for green products. Environ. Sci. Pollut. Res. 2021, 28, 61408-61422. [CrossRef]

17. Corsini, F.; Frey, M. Exploring the development of environmentally sustainable products through reward-based crowdfunding. Electron. Commer. Res. 2021, 1-21. [CrossRef]

18. Wierzbicka, K. Crowdfuning as a method of financing ecological project. Econ. Environ. 2017, 4, $249-262$.

19. Wardell, S. To wish you well: The biopolitical subjectivities of medical crowdfunders during and after Aotearoa New Zealand's COVID-19 lockdown. BioSocieties 2021, 1-27. [CrossRef]

20. Kuratko, D.F.; Audretsch, D.B. The future of entrepreneurship: The few or the many? Small Bus. Econ. 2021, 24, 1-10. [CrossRef]

21. Alva, E.; Vivas, V.; Urcia, M. Entrepreneurial bricolage: Crowdfunding for female entrepreneurs during COVID-19 pandemic. J. Entrep. Emerg. Econ. 2021, ahead-of-publication. [CrossRef]

22. Kneese, T. Keep it Oakland: E-commerce meets social justice. Media Cult. Soc. 2021, 01634437211048342. [CrossRef]

23. Huang, Y.C.; Wu, Y.C.J. The effects of organizational factors on green new product success: Evidence from high-tech industries in Taiwan. Manag. Decis. 2010, 48, 1539-1567. [CrossRef]

24. Hsiao, T.-Y.; Chuang, C.-M.; Kuo, N.-W.; Yu, S.M.-F. Establishing attributes of an environmental management system for green hotel evaluation. Int. J. Hosp. Manag. 2013, 36, 197-208. [CrossRef]

25. Chang, C.-H. The Determinants of Green Product Innovation Performance. Corp. Soc. Responsib. Environ. Manag. 2014, 23, 65-76. [CrossRef]

26. Tu, Y.-W.; Tu, J.-C.; Jhangr, Y.-S. Analyzing Key Success Factors of Green Brands for Enterprises in Taiwan. Euras. J. Math. Sci. Technol. Educ. 2016, 12, 1327-1346. [CrossRef]

27. Yan, B.F.; Lee, S.H. Principle study on the design green for Taiwan residential area. In Proceedings of the Conference on Central Europe towards Sustainable Building 2013, Prague, Czech Republic, 26-28 June 2013. 
28. Liao, L.Y.; Chiang, C.M.; Chen, C.C. Variance analysis from an inter laboratory comparison about different emission test methods by a certified green buildingmaterial in Taiwan. In Proceedings of the International Conference on Materials and Products Manufacturing Technology, Chengdu, China, 28-30 October 2011.

29. Han, F.; Izeng, S.Y. The processes of practicing green-mark of printing companies in Taiwan. In Proceedings of the 2nd China Academic Conference on Printing and Packaging, Beijing, China, 19-20 October 2012.

30. Chen, C.C. Development of a framework for sustainable uses of resources: More paper and less plastics? Environ. Int. 2006, 32, 478-486. [CrossRef] [PubMed]

31. Sojeong, O.; Lim, D. A study on reward-based crowdfunding and its efficiency viewed from the projects of Korea Tumblbug and Taiwan FlyingV. Glob. Cult. Content. 2017, 26, 115-130.

32. Hsieh, H.-C.; Hsieh, Y.-C.; Vu, T.H.C. How social movements influence crowdfunding success. Pacific-Basin Financ. J. 2018, 53, 308-320. [CrossRef]

33. Ziaei, M.; Ketabi, S.; Ghandehari, M. Integrative design, production, and marketing policy for a configurable product family. Int. J. Manag. Sci. Eng. Manag. 2020, 16, 43-57. [CrossRef]

34. Du, Q.; Li, J.; Du, Y.; Wang, G.A.; Fan, W. Predicting crowdfunding project success based on backers' language preferences. J. Assoc. Inf. Sci. Technol. 2021, 72, 1558-1574. [CrossRef]

35. Guan, L. A Short literature review on reward-based crowdfunding. In Proceedings of the 13th International Conference on Service Systems and Service Management, Kunming, China, 24-26 June 2016.

36. Li, Z.-T.; Zhang, C.-H.; Kong, W.; Lyu, R.-X. The optimal product-line design and incentive mechanism in a supply chain with customer environmental awareness. J. Ind. Manag. Optim. 2021. [CrossRef]

37. Yang, J.; Su, J.; Song, L. Selection of Manufacturing Enterprise Innovation Design Project Based on Consumer's Green Preferences. Sustainability 2019, 11, 1375. [CrossRef]

38. Zhang, J.S.; Li, M. The profit model design and development strategy of Industry 4.0 under the concept of green and low-carbon. Int. J. Technol. Manag. 2020, 84, 177-196. [CrossRef]

39. He, B.; Tang, W.; Huang, S.; Hou, S.; Cai, H. Towards low-carbon product architecture using structural optimization for lightweight. Int. J. Adv. Manuf. Technol. 2015, 83, 1419-1429. [CrossRef]

40. Chen, W. Choice and application of green materials in product. In Proceedings of the 2016 International Conference on Advanced Materials Science and Environmental Engineering, Chiang Mai, Thailand, 26-27 June 2016.

41. Braun, G.; Som, C.; Schmutz, M.; Hischier, R. Environmental Consequences of Closing the Textile Loop-Life Cycle Assessment of a Circular Polyester Jacket. Appl. Sci. 2021, 11, 2964. [CrossRef]

42. Wu, H.-C.; Tsai, H.-R.; Chen, T.-C.; Hsu, K.-W. Energy-Efficient Production Planning Using a Two-Stage Fuzzy Approach. Mathematics 2021, 9, 1101. [CrossRef]

43. Sharma, V.; Sharma, V.; Karwasra, K. A decision framework for green manufacturing indicators using fuzzy AHP-ELECTRE I: A case study of the steering system manufacturer. Int. J. Sustain. Eng. 2021, 14, 1332-1341. [CrossRef]

44. Yang, C.-M. An improved multiple quality characteristic analysis chart for simultaneous monitoring of process mean and variance of steering knuckle pin for green manufacturing. Qual. Eng. 2021, 33, 383-394. [CrossRef]

45. Sharma, A.P. Consumers' purchase behavior and green marketing: A synthesis, review and agenda. Int. J. Consum. Stud. 2021, 45, 1217-1238. [CrossRef]

46. Dahlquist, S.H. How green product demands influence industrial buyer/seller relationships, Knowledge and marketing dynamic capabilities. J. Bus. Res. 2021, 136, 402-413. [CrossRef]

47. Dogbe, C.S.K.; Bamfo, B.A.; Pomegbe, W.W.K. Market orientation and new product success relationship: The role of innovation capability, absorptive capacity, green brand positioning. Int. J. Innov. Manag. 2020, 25, 2150033. [CrossRef]

48. Khan, M.I.; Khalid, S.; Zaman, U.; José, A.E.; Ferreira, P. Green Paradox in Emerging Tourism Supply Chains: Achieving Green Consumption Behavior through Strategic Green Marketing Orientation, Brand Social Responsibility, and Green Image. Int. J. Environ. Res. Public Heal. 2021, 18, 9626. [CrossRef] [PubMed]

49. Li, Y.; Wang, G.; Zuo, J. Assessing Green-Building Policies with Structural Consistency and Behavioral Coherence: A Framework of Effectiveness and Efficiency. J. Constr. Eng. Manag. 2021, 147, 04021149. [CrossRef]

50. Calvo, F.; Gómez, J.M.; Alvarez, O.; Ricardez-Sandoval, L. Trends and perspectives on emulsified product design. Curr. Opin. Chem. Eng. 2021, 35, 100745. [CrossRef]

51. Makhtar, S.Z.; Amirah, A.S.N.; Ab Wahab, M.; Hassan, Z.; Hamid, S. Study of environmental awareness, practices and behaviors among UniMAP students. In Proceedings of the 3rd International Conference on Civil and Environmental Engineering, Electric Network, Malaysia, 18 November 2020.

52. Kobayashi, T.; Nakajima, L. Sustainable development goals for advanced materials provided by industrial wastes and biomass sources. Curr. Opin. Green Sustain. Chem. 2021, 28, 100439. [CrossRef]

53. Kalsoom, Q.; Khanam, A.; Qureshi, N. Collaborative reflection on environmental practices: A vehicle for environmental education in teacher education. Reflective Pr. 2021, 23, 1-15. [CrossRef]

54. Hapuwatte, B.M.; Jawahir, I.S. Closed-loop sustainable product design for circular economy. J. Ind. Ecol. 2021, 25, 1430-1446. [CrossRef]

55. Subramoniam, R.; Sundin, E.; Subramoniam, S.; Huisingh, D. Riding the Digital Product Life Cycle Waves towards a Circular Economy. Sustainability 2021, 13, 8960. [CrossRef] 
56. Ko, Y.-T. Modeling an Innovative Green Design Method for Sustainable Products. Sustainability 2020, 12, 3351. [CrossRef]

57. Shivankar, S.D.; Deivanathan, R. Product design change propagation in automotive supply chain considering product life cycle. CIRP J. Manuf. Sci. Tec. 2021, 35, 390-399. [CrossRef]

58. He, B.; Li, F.; Cao, X.; Li, T. Product Sustainable Design: A Review from the Environmental, Economic, and Social Aspects. J. Comput. Inf. Sci. Eng. 2020, 20, 1-75. [CrossRef]

59. Feng, C.H.; Huang, S.; Bai, G.Z. A group decision making method for sustainable design using intuitionistic fuzzy preference relations in the conceptual design stage. J. Clean. Prod. 2020, 243, 118640. [CrossRef]

60. Son, D.; Kim, S.; Jeong, B. Sustainable part consolidation model for customized products in closed-loop supply chain with additive manufacturing hub. Addit. Manuf. 2020, 37, 101643. [CrossRef]

61. Gani, A.; Bhanot, N.; Talib, F.; Asjad, M. An integrated DEMATEL-MMDE-ISM approach for analyzing environmental sustainability indicators in MSMEs. Environ. Sci. Pollut. Res. 2021, 29, 2035-2051. [CrossRef] [PubMed]

62. Tanveer, M.; Ahmad, A.-R.; Mahmood, H.; Haq, I. Role of Ethical Marketing in Driving Consumer Brand Relationships and Brand Loyalty: A Sustainable Marketing Approach. Sustainability 2021, 13, 6839. [CrossRef]

63. Gustavo, J.U., Jr.; Trento, L.R.; de Souza, M.; Pereira, G.M.; de Sousa Jabbour, A.B.L.; Ndubisi, N.O.; Jabbour, C.J.C.; Borchardt, M.; Zvirtes, L. Green marketing in supermarkets: Conventional and digitized marketing alternatives to reduce waste. J. Clean. Prod. 2021, 296, 126531. [CrossRef]

64. Nadanyiova, M.; Gajanova, L.; Majerova, J. Green marketing as a part of the socially responsible brand's communication from the aspect of generational stratification. Sustainability 2020, 12, 7118. [CrossRef]

65. Berne-Manero, C.; Marzo-Navarro, M. Exploring How Influencer and Relationship Marketing Serve Corporate Sustainability. Sustainability 2020, 12, 4392. [CrossRef]

66. Sajan, M.P.; Shalij, P.R.; Ramesh, A.; Augustine, P.B. Lean manufacturing practices in Indian manufacturing SMEs and their effect on sustainability performance. J. Manuf. Technol. Manag. 2017, 28, 772-793.

67. Kim, S.; Shin, N.; Park, S. Closed-Loop Supply Chain Coordination Under a Reward-Penalty and a Manufacturer's Subsidy Policy. Sustainability 2020, 12, 9329. [CrossRef]

68. Singhal, D.; Tripathy, S.; Jena, S. Remanufacturing for the circular economy: Study and evaluation of critical factors. Resour. Conserv. Recycl. 2020, 156, 104681. [CrossRef]

69. Meng, L.; Qiang, Q.; Huang, Z.; Zhang, B.; Yang, Y. Optimal Pricing Strategy and Government Consumption Subsidy Policy in Closed-Loop Supply Chain with Third-Party Remanufacturer. Sustainability 2020, 12, 2411. [CrossRef]

70. Xu, J.; Cao, J.; Wang, Y.; Shi, X.; Zeng, J. Evolutionary Game on Government Regulation and Green Supply Chain Decision-Making. Energies 2020, 13, 620. [CrossRef]

71. Mondal, C.; Giri, B.C. Analyzing a manufacturer-retailer sustainable supply chain under cap-and-trade policy and revenue sharing contract. Oper. Res. 2021, 25, 1-36. [CrossRef]

72. Liu, P. Pricing rules of Green Supply Chain considering Big Data information inputs and cost-sharing model. Soft Comput. 2021, 25, 1-17. [CrossRef]

73. Zhang, Z.; Jie, Y.; Zhu, J.; Zhu, Z.; Chen, H.; Lu, Q.; Zeng, Y.; Cao, X.; Wang, N.; Wang, Z. Paper triboelectric nanogenerator designed for continuous reuse and quick construction. Nano Res. 2021, 15, 1109-1114. [CrossRef]

74. Wang, Y.; Fu, P. Integration performance statistics of green suppliers based on fuzzy mathematics and BP neural network. J. Intell. Fuzzy Syst. 2021, 40, 2083-2094. [CrossRef]

75. Wang, Z. Research on the ecological model of enterprise management. Fresenius Environ. Bull. 2020, 29, 6028-6032.

76. Shieh, M.D.; Chen, C.N.; Hsieha, H.Y. Empirical study on the effect of green product design on environmental trust and purchase intention. J. Environ. Prot. Ecol. 2020, 21, 2271-2278.

77. Kunz, M.M.; Bretschneider, U.; Leimeister, J.M. Reward-based Crowdfunding. In Handbuch Digitale Wirtschaft; Kollmann, T., Ed.; Springer: Wiesbaden, Germany, 2020; pp. 755-787.

78. Zhukova, V.; Corte-Leon, P.; Blanco, J.M.; Ipatov, M.; Gonzalez, J.; Zhukov, A. Electronic Surveillance and Security Applications of Magnetic Microwires. Chemosensors 2021, 9, 100. [CrossRef]

79. Cosma, S.; Grasso, A.G.; Pattarin, F.; Pedrazzoli, A. Platforms' partner networks: The missing link in crowdfunding performance. Eur. J. Innov. Manag. 2021; ahead-of-print. [CrossRef]

80. Rossolini, M.; Pedrazzoli, A.; Ronconi, A. Greening crowdfunding campaigns: An investigation of message framing and effective communication strategies for funding success. Int. J. Bank Mark. 2021, 39, 1395-1419. [CrossRef]

81. Dos Santos, F.; Israel, J.; de Souza, F.; Guilherme, L. What makes crowdfunding campaigns successful? Innovar 2021, 31, 21-33.

82. Hsieh, H.-C.; Vu, T.H.C. The impact of economic policy uncertainty on crowdfunding success. J. Int. Financ. Mark. Instit. Money 2021, 75, 101418. [CrossRef]

83. Shim, W.J.; Lee, E.J. A study of other backers' social group size and social presence on web-based crowdfunding platforms impacting participation intent. J. Conv. Cult. Technol. 2021, 7, 397-404.

84. Jeong, N.; Kim, C.O. Factors affecting the success of fashion crowdfunding: Focusing on social value and product value. J. Kor. Entrep. Soc. 2020, 15, 1-29.

85. Sherman, A.; Axelrad, H. A qualitative study on money, well-being and serial crowdfunding. Balt. J. Manag. 2020, 16, 97-112. [CrossRef] 
86. Ryoba, M.; Qu, S.; Ji, Y.; Qu, D. The Right Time for Crowd Communication during Campaigns for Sustainable Success of Crowdfunding: Evidence from Kickstarter Platform. Sustainability 2020, 12, 7642. [CrossRef]

87. Yin, C.; Liu, L.; Mirkovski, K. Does more crowd participation bring more value to crowdfunding projects? The perspective of crowd capital. Internet Res. 2019, 29, 1149-1170. [CrossRef]

88. De Larrea, G.L.; Altin, M.; Singh, D. Determinants of success of restaurant crowdfunding. Int. J. Hosp. Manag. 2018, 78, 150-158. [CrossRef]

89. Belleflamme, P.; Lambert, T.; Schwienbacher, A. Crowdfunding: Tapping the right crowd. J. Bus. Ventur. 2014, 29, 585-609. [CrossRef]

90. Saaty, T.L. The Analytic Hierarchy Process; McGraw-Hill: New York, NY, USA, 1980.

91. Rong, T.S. The Application of Expert Choice in AHP; Wu-Nan: Taipei, Taiwan, 2011.

92. Arifah, J.N.; Dalimunthe, Z. The Impact of Financial Literacy on the Investment Decision of Non-Donation-Based Crowdfunding in Indonesia. Int. J. Bus. Soc. 2021, 21, 1045-1057. [CrossRef]

93. Tu, J.C.; Ke, Y.Z.; Chen, X.Z.; Zhang, X.T.; Huang, Y.Z.; Luo, C.Y.; Hu, Q.J.; Cai, D.Y.; Zhang, Y.X.; Wu, B.Y.; et al. Green Design Innovation and Design Practice; Qiguo: Taizhong, Taiwan, 2007. 